\title{
VISION OF CHILDREN IN AN ORPHANAGE ABOUT FAMILY AND FAMILY LIFE
}

\author{
Boris Pták, ${ }^{1}$ Jozef Fecenko, ${ }^{2}$ Bibiana Barabasová, ${ }^{3}$ Nikola Benecová ${ }^{4}$
}

\begin{abstract}
The aim of this paper is to refer the issue of the vision of children in an orphanage about family and family life. The aim of the research is to identify, analyze and describe their own idea of their future family and family life. The theoretical introduction briefly describes the family, types and functions of the family and the institution of a children's home. In this study we used a quantitative questionnaire method and the techniques of descriptive (mean, median, mode) and inferential statistics. Based on the author's questionnaire we can confirm and subvert predefined research questions and draws a clear conclusion. Children from orphanages state that the most important value for them is family. In this regard, the contribution shows importance of family and recommendation of counseling for children before leaving the orphanage to help have a successful family life in the future.
\end{abstract}

UDC Classification: 304; DOI: http://dx.doi.org/10.12955/cbup.v5.1025

Keywords: Orphanage, Child, Family

\section{Introduction}

"The family is based on marriage, which is a relationship between a man and a woman. For her the stability of the marital relationship is most important, hence its durability to the death of a spouse, and just such can create the most favorable conditions for the healthy mental and physical development of children. Therefore it is very important that children grow up in a family that is rightly considered as the basic cell of society" (Tománek, 2015).

The target group consists of children from orphanages from all over Slovakia. To conduct research in advance, we asked the orphanages for permission.

\section{Characteristics of Families}

Family ties, or relations we can understand in two ways - objectively and subjectively. Objectively we see family from a multiple perspective for example: legal aspect - law (standards, laws); generally through the customs, myths, stories, traditions; religious aspect - religious beliefs, faith itself and economic-economic aspects - material status and economic activity. The subjective approach is based on solidarity and alliances with other members of one another. This is reflected in the realm of ideas associated with desires, feelings, and in the sphere of shared values (Drapała, 2008).

\subsection{Function of family}

One of the functions of the family has always been and will be, to protect its members against various aspects of society such as the economic and social problems, satisfying emotional needs, the need for parenthood and to socialize our children, and many others (Žilová, 2010).

Many other authors describe family function in more details. Tománek (2015) describes the functions of the family as:

1. Biological-reproductive function - new members of society are born in it. Although the sexual relations are also outside of the family, the society tries to motivate its members to start a family, and in this family bring up children,

2. Economic function - the function of the family as self-employed households that manage their funds,

3. Socializing function - generational transmission of social culture. How children will succeed in the future also depends on socialization in the family,

4. Emotional function - this function provides for its members protection, care, emotional support especially when they are going through challenging times in life,

5. Regulatory function - the society determines what are the boundaries of sexual behavior, which describes to its members with who they can enter into sexual relationship and prohibits this relationship between relatives,

\footnotetext{
${ }^{1}$ Catholic University in Ružomberok, Faculty of Education, boris.ptak@gmail.com

${ }^{2}$ Catholic University in Ružomberok, Faculty of Education, jozef.fecenko2@ gmail.com

${ }^{3}$ Catholic University in Ružomberok, Faculty of Education, bibiana.barabasova@gmail.com

${ }^{4}$ Catholic University in Ružomberok, Faculty of Education, nikolabenecova81@ gmail.com
} 
6. Religious function - parental influence on children through religion,

7. Educational function - priority for every single family,

8. Learning function - family is the very first educational institution for child,

9. Advisory functions - this function is for advice and help for children from their older siblings, parents or grandparents, which must be complied with the rules of ethics, decency and truth,

10. Vocational function - helping children by their parents when they choose their future profession based on their skills, their own possibilities and limits. They don't push their children to future jobs which are unattainable for them,

11. Regeneration and relaxation function - proper use of free time to rest - leisure activities for children and parents. This function is usually not usedbecause of financial problems in families and parents spend more time by working.

Drapała (2008) states that the individual functions are different and depend on the nature of society in which the family lives. It is influenced by state, territory, religion, etc. We can not ignore factors such as education, economic status, allocation of responsibilities and authority in the family, age of children and the linkages between individual members.

\subsection{Types of Families}

Each family in the world is unique and authentic. Many different authors present their own divisions of the functions of families and typology of families. We present the division of Almásiová (2012), which divides the family in terms of:

\section{Leadership role in the family}

a. patriarchal - the oldest male member leading the whole family,

b. matriarchal family - mother takes a leadership role - a woman,

c. egalitarian - the leadership role is shared between the both sexes;

\section{Housing after the marriage}

a. patrilocal - coexistence newlyweds move into the residence of the husband,

b. matrilocal - coexistence newlyweds move into the residence of the wife,

c. non-local - the coexistence of newlyweds in a completely new environment (most currently used).

Rusnáková (2007) adds further division of families:

1. Families in terms of the arrangement:

a. complete family - the educational process in the family is conducted by mother and father,

b. complete family (unstructured or disrupted) - based on the relationship of parents, disturbed relationships of its members fails to comply with the designated role in society;

c. single parent family - the educational process is conducted by only one of the parents (relatives), which is caused by the death of his parents, non-closure of the marriage or divorce;

d. criminal family - patterns of behavior are in delinquent level, all the negatives that children see they see as normal and natural, but this doesn't mean that every member will inevitably be delinquent.

\section{Family in terms of education}

a. perfectionist family - one or both parents require specific forms of behavior,

b. inadequate family - a family type that is immature, seeking help from outside (family, relatives, community, social workers);

c. egocentric family - one or both parents are more interested in career advancement, mostly wealthy families of cold relations,

d. asocial family- families that are characterized by aggressive and deviant behavior.

\section{Specification of orphanages}

Orphanages as institutions in the Slovak Republic represent organizations whose primary purpose is mainly to create a substitute environment which provide care for children who for many different reasons can't be brought up in an environment of their biological family.

Since the family is in our fundamental cell of viewing the whole society and its importance in the life of a child is almost irreplaceable in defining competencies of orphanages in Slovakia, it is necessary to choose an integrative approach and proceed individually in relation to each child. The child and its 
needs and requirements must be considered very sensitive because when the child gets into the care of the orphanage, they are going through a very difficult period of their life, which is associated with feelings of separation, fear, sadness, hopelessness and so on. At this point, significantly changing the existing relationship bonds, which are in most cases not associated with positive emotions and there is space for the creation of new bonds, whose role should be to create the conditions for successful integration into society and to prepare the child for adult life.

It is important to remember that the goal of foster homes should only be a temporary replacement of the natural family environment and it is therefore necessary to try to cooperate with other institutions to find out in what relationship binding to a specific child, failed in its original environment, if it is possible try to fix these relations and return the child to their natural environment.

\subsection{Organization, structure and operation of orphanages}

Organization of orphanages in the Slovak Republic is formed by 3 basic steps of the Government Regulation no. 5/2016:

1. Micromanagement - is a central management level, carried out by the Ministry of Labour, Social Affairs and Family of the Slovak Republic,

2. Middle level of management - which is the responsibility of the Central Office of Labour, Social Affairs and Family of the Slovak Republic,

3. Micromanagement - it's a basic control to which management belongs under different orphanages.

Based on the Law no. 36/2005 Act of the family, child care in orphanages is generally provided in the residence form until they reach the age of majority, 18 years of age. In cases where the person has a specific request, their can stay in the orphanage be extended, but only according to legal conditions and until 25 years of age.

This legislative correction, in our opinion is done like this because at the age of majority it is a difficult situation for a person when they have to enter to independent lives and integrate into society (Act no. 36/2005 Coll., the Family Act, 2005).

The child is accepted by a final court decision into an orphanage, which the court ordered inpatient care, by final court decision on imposing an educational measure or as a result of interim relief the court pursuant to special legislation (Act no. 36/2005 Coll. Act family, 2005).

Many times in our opinion is the problem with integration into society - with becoming independent. It must be said that integration into society is an important step, which involves great responsibility, concern, anxiety and in the case of individuals who grew up in normal conditions their biological families whose ties have been disrupted in more serious way.

We think that it must be harder for a person who went through many critical situations which had the result of disrupting relationship ties especially in relation to their own parents because ultimately, they had to be depended on alternative care in an orphanage.

\section{Research}

The subject of our research are the visions of children in an orphanage of their future family and family life and also how they see these factors. Specifically, we focus on two factors - the perception of family and family life now and the idea of the family in the future.

\subsection{Object of research}

Our research sample are children from orphanages from all over the Slovakia. The age range of research sample was:

14 years old $(20,8 \%)$,

15 years old $(30,6 \%)$,

16 years old $(23,6 \%)$ and

17 years old $(25 \%)$.

\subsection{Purpose of research}

The aim of the research is to identify, analyze and describe their own idea of their future family and family life. 


\subsection{Partial goals}

So that we know better set a target of research, we created a few targets.

a. Find out how respondents perceive (define) family.

b. Find out the views of respondents on how should their family look like in the future.

3.4 Research questions

1. Research question 1: How respondents perceive the concept of family?

2. Research Question 2: How do respondents see their future family?

3.5 Research Methodology

In our empirical section, we used a quantitative questionnaire method. The author's questionnaire included closed and open questions. In the closed questions respondents were offered the choice of options, the respondents can choose only one of them, and for one of the questions they can choose multiple options. In the open questions, respondents have space to create their own answers. Children will be filling out the questionnaire in the presence of the Contractor, which will at any time answer to their questions. Based on the questionnaire we confirm / refute by us predefined research questions and we draw a clear conclusion.

\subsection{Characteristics of the research sample and timing of research}

The author's questionnaire was designed for 72 children from various orphanages from all over Slovakia; the selection of the children from the orphanages for the research sample was taken at random. Questionnaires were distributed among respondents personally and their return was $100 \%$. For all statistical operations we used the IMB SPSS statistic program 23.

\subsection{Interpretation of research results}

As the first open question was: What do you think is the family? After reading all the questionnaires some answers were the same, so we decided to divide them into categories. The most frequent response of our respondents was that, according their opinion family consists of: the closest people who they love and held in difficult situations, trust you, also the family for them is a place where they feel safe and are able to find understanding. Another larger group of respondents sees the family as emotion, respectively, happiness, joy and responsibility. Others, probably on the basis of their past, perceive the concept of family as something that is important or that the family is the only basis of life, but that's all. They were found also those for whom the concept of family does not mean anything, because it is their own family disappointed them repeatedly and they can't know forget that feeling of frustration.

The following bellow are example answers to above question, we have decided to quote directly from the questionnaire because it seemed to us the most interesting:

- $\quad$ "Family for me is happiness in life, it is the best thing in life. When you have no mother, father or siblings you do not have anything!"

- $\quad$ "The family does not have to be biological. Family should consist of people who love each other. "

- "Nothing, family to me now means nothing, because in life I went through a lot of disappointing by my family."

- $\quad$ "The Family - a circle of the closest ones, where everyone is honest with yourself. Consist of father and mother. It is mainly a feeling of love to someone you care for. You have to fall back on, ask him for help. "

Second open question in our study was: How our respondents see their own family in the future. In this question again, we have more than half of respondents agreed, in answer that they want their future family to be formed "from the good wife / husband" to have children together and their own housing. They want in their family to feel love and understanding, and to always have all been together. Some of them want bigger family some of them - in meaning of the number of children that would like to have. Other ideas about how they see their family were the modest description and that they would like to have a family with family members who love each other. Other answers were colder such as many of the respondents do not want to imagine their family, or whatever it will look like but they don't want to have family like they already have.

We also chose examples of the most interesting answers: 
- $\quad$ "My family should be harmonious. There should not be lies in it. We should be happy. "

- $\quad$ "Perfect $=$ harmonious, cohesive, supportive, particularly to provide members of security, reassurance and knowing that somewhere are and always will belong."

- "My own family is perfect. With children I have a friendly relationship, but I will be strict, tactful and fair. Especially I will not discriminate. "

With the third and the last question we investigated the importance of values, according to respondents. The level of importance to indicate on a scale from 1 to 5 , where $1=$ very important and $5=$ not important at all. As you can see in Table 1 which shows the mean values of responses respondents identified as the most important value (average 1.19) health, the family itself was in second place. The third most important were two values - their own housing, and the independence and education (average 1.46). Other values in order were friends, money, career, fun car. A big surprise was that the respondents reported religion as the least important value (average 2.39).

\begin{tabular}{|l|l|}
\hline \multicolumn{1}{|c|}{ Table 1: The importance of respondents values } & \\
\hline \multicolumn{1}{|c|}{ Values } & \multicolumn{1}{|c|}{ Arithmetic mean } \\
\hline Health & 1.19 \\
\hline Family & 1.32 \\
\hline Own housing & 1.46 \\
\hline Education & 1.46 \\
\hline Children & 1.47 \\
\hline Friends & 1.67 \\
\hline Money & 1.75 \\
\hline Career & 1.96 \\
\hline Fun & 2.11 \\
\hline Car & 2.35 \\
\hline Religion & 2.39 \\
\hline Source: Author & \\
\hline
\end{tabular}

\section{Discussion}

The empirical part of our work was focused on the idea of children from orphanage of family and family life. In the following discussion, we answer questions and we complete answers by statements from various authors on the issue.

\section{How respondents understand the concept of family?}

Children are in orphanages for some different reasons. One of these reasons is the failure of parents. Therefore, we asked what the children in foster care think that the family is and how they see it and what they think of first when they hear the word family. In evaluating the responses of our respondents, the most surprising fact was a very small number of them responded about their vision and perception of families with answers consisting of mother, father - parents and siblings. Most of them described family as feeling, just a circle of people with whom they feel safe and meet the various positive qualities that the respondents reported (eg. honesty, love, security, sincerity).

Matějček (2007) in his publications gives an important insight that the child is coming to the world, is equipped with everything what is needed for living in this world and has every tools to be able to have a human relationship. People with who the child is building a relationship are parents, but when this relationship is absent, it is understandable that the perception of the concept of family is a little different. Some respondents are by this absence of that relationship, and therefore the absence of attachment stigmatizing more.

Nosková (In Mosty k rodine 2011 No. 2) mentions that children who come from risk families create some chaotic bonds, which can lead to the disruption of the development of emotional ties. They have 
in themselves a lack of confidence, feelings of anger, loneliness, etc. What they say they are expressed in terms of the family for them does not mean nothing, because it is their family who is hurting them again and again.

\section{How respondents represent their future family?}

Our second question is more less related to the previous one. Everything that we mentioned affects our respondent's next answers about how they see their family in the future. The majority of respondents do not want to repeat the mistakes of their parents and want to have a husband / wife, children, his own house, they want just harmony inside of their family.

Výbochová (In Mosty k rodine 2011, no. 2) describes that first relationships for the childare of great importance and the first binding that is not built, affects all its future ties. The author argues that this is the case of children from orphanages. Based on this we conclude that children's ideas about their future family is more or less positive, as real in the future may not be valid and will confirm.

\section{What is respondent's attitude to the selected values?}

Children determined from the selected values the importance of their own opinion. From the results, we can say that the most important value they considered the family. This result is attributed to the fact that their family disappointed and failed them and they realize that in the future they do not want to make the same mistake or worse. A surprising phenomenon for us was that religion in children was in the last place in terms what they deem most important. The values that children consider as important are related to how they fill their needs and what they consider as missing for them.

Rusnáková and Szabóová (2014), based on practical experience argue that orphanage fill the following needs of children: biological, psycho-social and material. If those needs are not filled sufficiently, children most likely won't be able to be ready for adulthood and parenthood. Since orphanages can't fill $100 \%$ of the biological needs of children as they were filled with the family, we believe that is the reason that children have chosen for themselves the most important value as: family.

\section{$5 \quad$ Conclusion and recommendations for practice}

Children from orphanages could pass through counseling provided by qualified professionals and receive training before leaving the orphanage for potential family life. Intermediaries of this kind of counseling might be different NGOs that work with orphanages.

Social workers and orphanage workers could attend courses on family guidance and counseling which would help children from the orphanage to be better prepared for family life in the future.

Lectures, meetings, meetings of self-help groups, which could result in "former foster kids" who have already had their own family and their experiences could pass to those kids and in those meetings they could assist in the preparedness for family life in the future.

\section{References}

Almášiová, A. Sociológia. Ružomberok : Verbum - Vydavatel'stvo Katolíckej Univerzity V Ružomberku, 2012. Isbn 97880-8084-878-1

Drapała, A. 2008. Vzt'ahy Rodičov S Det'mi V Obdobi Adolescencie. Ružomberok: Katolícka Univerzita, 2008. 233 S. Isbn 978-80-8084-392-2

Matějček, Z. 2007. Co Děti Nejvic Potřebují? Praha: Portál, 2007, 112 S. Isbn 978-80-7367-504-2

Rusnáková, M. 2007. Rodina V Slovenskej Spoločnosti V Kontexte Sociálnej Práce. Ružomberok: Pedagogická Fakulta Katolíckej Univerzity V Ružomberku, 2007. 167 S. Isbn 978-80-8084-248-2

Rusnáková, M., Szabóová M. 2014. Prorodinné Správanie Mladých Dospelých Z Detských Domovov. Ružomberok: Verbum, 2014. 101 S. Isbn 978-80-561-0126-1

Tománek, P. 2015. Rodina-Výchova-Spoločnost: Výzvy A Perspektívy. 1. Vydanie. Brno: Tribun Eu, 2015. 399 S. Isbn 97880-263-0775-4

Zákon Nr Sr Č. 36/2005 Z. Z. O Rodine A O Zmene A Doplnení Niektorých Zákonov

Žilová, A. 2010. Manželstvo Dnes. 1. Vydanie. Ružomberok: Verbum, 2010. 260 S. Isbn 978-80-8084-570-4

Http://Www.Usmev.Sk/Index.Php?Option=Com_Content\&Task=View\&Id=15 